ARTICLE

DOI: $10.1038 / \mathrm{s} 41467-017-01428-0$

\title{
Convenient iron-catalyzed reductive aminations without hydrogen for selective synthesis of $\mathrm{N}$-methylamines
}

Kishore Natte ${ }^{1}$, Helfried Neumann ${ }^{1}$, Rajenahally V. Jagadeesh ${ }^{1} \&$ Matthias Beller (i) ${ }^{1}$

$\mathrm{N}$-Methylated amines play an important role in regulating the biological and pharmaceutical properties of all kinds of life science molecules. In general, this class of compounds is synthesized via reductive amination reactions using high pressure of molecular hydrogen. Thus, on laboratory scale especially in drug discovery, activated (toxic) methyl compounds such as methyl iodide and dimethyl sulfate are still employed, which also generate significant amounts of waste. Therefore, the development of more convenient and operationally simple processes for the synthesis of advanced $\mathrm{N}$-methylamines is highly desired. Herein, we report the synthesis of functionalized and structurally diverse $N$-methylamines directly from nitroarenes and paraformaldehyde, in which the latter acts as both methylation and reducing agent in the presence of reusable iron oxide catalyst. The general applicability of this protocol is demonstrated by the synthesis of $>50$ important $N$-methylamines including highly selective reductive $\mathrm{N}$-methylations of life science molecules and actual drugs, namely hordenine, venlafaxine, imipramine and amitriptyline.

\footnotetext{
${ }^{1}$ Leibniz-Institute for Catalysis at the University of Rostock, Albert-Einstein-Straße 29 a, D-18059 Rostock, Germany. Correspondence and requests for materials should be addressed to R.V.J. (email: Jagadeesh.Rajenahally@catalysis.de) or to M.B. (email: Matthias.Beller@catalysis.de)
} 
T he development of new and convenient methodologies for the synthesis and modification of advanced life science intermediates remains an important goal for chemistry. Most of the known agrochemicals and pharmaceuticals contain amino groups, which represent a key scaffold in the vast majority of bioactive compounds. Hence, the synthesis and functionalization of amines continues to attract the interest of researchers from chemistry, biology, and medicine. Among the known reactions of amines, especially $\mathrm{N}$-methylation is of importance to regulate the biological and pharmaceutical activities of life science molecules ${ }^{1-6}$. For example, in nature $\mathrm{N}$-methylation of peptides and DNA controls biological functions and plays a vital role in epigenetic changes in gene expression for cellular phenotypes ${ }^{6}$. Interestingly, this comparatively small structural change can activate large protein complexes and also controls the action of enzymes and antibodies as well as the pharmacokinetics and drug delivery ${ }^{1,2}$. In addition, $\mathrm{N}$ methylation of small bioactive molecules modulates the cytotoxicity and importantly makes them more lipophilic which enhances their solubility in bio-membranes ${ }^{7}$. Consequently, top selling drugs such as olanzapine, oxycodone, imatinib, viagra and venlafaxine contain $\mathrm{N}$-methylamino groups (Fig. 1), which play a significant role in their activities ${ }^{8}$.

Besides these biological functions, $\mathrm{N}$-methylamines represent important intermediates for bulk and fine chemicals as well as materials ${ }^{9-11}$. More specifically, methylamines such as $\mathrm{MeNH}_{2}$, $\mathrm{Me}_{2} \mathrm{NH}$ and $\mathrm{Me}_{3} \mathrm{~N}$ are produced in $>1$ million tons per year by reaction of ammonia with methanol ${ }^{12}$. Notably, there is an increasing demand on these products, which grow annually by $4-5 \%$. Unfortunately, the applied catalysts require drastic conditions $\left(>200^{\circ} \mathrm{C}\right)$ and do not allow to produce higher value $\mathrm{N}$ methylamines. Hence, these products are often synthesized by reductive $N$-methylation reactions. Among them, the Eschweiler-Clarke methodology ${ }^{13,14}$ and reductive aminations, in which the corresponding amines and formaldehyde are converted to $\mathrm{N}$-methylamines in the presence of hydrogen or stoichiometric reducing agents ${ }^{15-17}$, prevail.

To perform selective reductive aminations of more advanced and multi-functionalized substrates the use of a proper catalyst is crucial. So far most of them are based on noble metals ${ }^{18}$. However, the development of earth-abundant metal catalysts is becoming increasingly important. In this regard, in the past decade especially iron became highly attractive due to its abundance $(4.7 \%$ in the earth's crust; second most abundant metal), bio-relevance and low toxicity, which makes it not only an ideal metal for catalysis but also for drug discovery and synthesis ${ }^{19-32}$. For example, molecular-defined iron complexes have been shown to promote catalytic hydrogenation $s^{27-29}$, dehydrogenations ${ }^{30,31}$, and aminations ${ }^{26,32}$. Despite these elegant achievements, heterogeneous iron catalysts are preferable due to their stability, reusability and easy separation.

In addition, it should be noted that a general problem of all these hydrogenations is the necessity of special equipment and the need for additional pressure of hydrogen. Therefore, on laboratory scale and in drug discovery still the use of activated but toxic methyl compounds is popular ${ }^{33,34}$. Although in recent years, more benign $N$-methylations using methanol ${ }^{35,36}$ and $\mathrm{CO}_{2}{ }^{37-39}$ have been disclosed, these methods are restricted regarding sensitive functional groups and substrate scope. Thus, the use of convenient reagents for selective methylation of life science molecules continues to be an important goal. In this regard, paraformaldehyde $e^{40-42}$, which is stable and easy to handle, can be a suitable methylation reagent.

Here, we show that reductive aminations of nitroarenes with paraformaldehyde proceed in the presence of an earth-abundant and reusable iron oxide-based nanocatalyst. The developed straightforward, convenient and step economic process avoids the necessity of any specialized equipment and also the need of additional reducing agents. Applying this operationally simple protocol, we synthesized a broad series of functionalized and structurally diverse $\mathrm{N}$-methylamines. The synthetic utility of this methodology is specifically demonstrated using various life science molecules including existing pharmaceuticals.

\section{Results}

Reaction Design. In general, $N$-methylated (hetero)aromatic amines are prepared in a two-step sequence from easily available nitroarenes (Fig. 2). Obviously, a straightforward direct transformation of nitroarenes is advantageous regarding step economy and price of substrates ${ }^{43-46}$. So far, noble metal-based catalysts, e.g., $\mathrm{Pd} / \mathrm{C}$, prevail in this reaction. To compare the activity of our recently developed $\mathrm{Fe}_{2} \mathrm{O}_{3} / \mathrm{NGr} @ \mathrm{C}$ material ${ }^{19}, 44$ with the common $\mathrm{Pd} / \mathrm{C}$ catalyst, the reductive $\mathrm{N}$-methylation of 4 -nitroanisole 1 with paraformaldehyde was used as a benchmark reaction. As shown in Table 1, both catalysts exhibited similar activity at different hydrogen pressure (1-50 bar) and produced the corresponding di-methylated amine 2 in $76-87 \%$ yield, respectively (Table 1, entries 1-6). Surprisingly, even without any external hydrogen this dimethylation reaction proceeded. However, it is important to note that under the latter conditions the $\mathrm{Fe}_{2} \mathrm{O}_{3}$ / NGr@C-catalyst is significantly more active compared to $\mathrm{Pd} / \mathrm{C}$ (Table 1, entries 7 and 8). As expected in the presence of the parent homogeneous iron complex or commercial $\mathrm{Fe}_{2} \mathrm{O}_{3}$, as well as pyrolyzed iron acetate on carbon no activity was observed (Supplementary Table 1, entries 1-8). However, related iron nanoparticles prepared by the pyrolysis of iron acetate-amine complexes, e.g., 2,2' -bipyridine, $2,2^{\prime} ; 6^{\prime}, 2^{\prime \prime}$-terpyridine, and 2,6-bis (2-benzimidazolyl)pyridine at varying temperatures on different heterogeneous supports showed some activity (Supplementary Table 1, entries 9-18).

Synthesis of $\mathbf{N}$-Methyl- and $\mathbf{N}, \mathbf{N}$-dimethylamines. After having a convenient protocol in hand for the model reaction, we investigated the reductive $N$-methylation of a broad range of

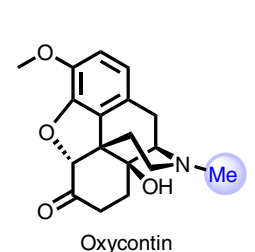

(Narcotic Analgesic)

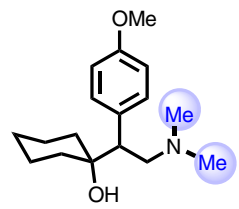

Venlafaxine (Antidepressent \& mood disorder)

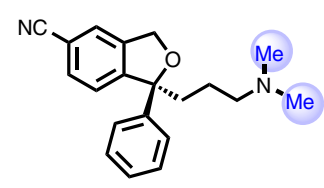

Lexapro

(Antidepressent \& mood disorder)

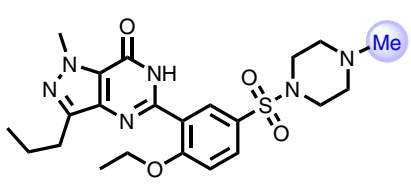

Viagra

(Erectile dysfunction)

Fig. 1 Top selling drugs: Selected important drugs containing N-methyl moiety 
substrates. In general, industrial bulk nitroarenes but also more demanding functionalized and heteroaromatic nitro compounds gave the corresponding $N, N$-dimethylamines in good to excellent yields (Fig. 3a-d). For organic synthesis it is of special importance to achieve chemoselective reductive $N$-methylation of nitroarenes in the presence of sensitive functional groups such as halogen, alcohols, thiols, ketone, ester, amide, sulfonamide and C-C triple and double bonds (Fig. 3b, c). Gratifyingly, in presence of all these functionalities the nitro group is selectively transformed to the corresponding $\mathrm{N}, \mathrm{N}$-dimethylamine. Heterocyclic diamines, which are important substructures in active life-science molecules, agrochemicals and advanced materials, are obtained up to $94 \%$ using this reductive amination protocol. As an example, 4dimethylaminopyridine (DMAP), a useful nucleophilic catalyst for a variety of reactions is prepared in a straightforward manner.

To demonstrate the applicability of this methodology further on, the methylation of nitro-substituted biologically active molecules to the corresponding $\mathrm{N}, \mathrm{N}$-dimethylated analogs was investigated (Fig. 4). Notably, reaction of calcium channel blockers (CCBs) ${ }^{47}$ which represent important drugs such as nimodipine, clinidipine and nicardipine produced the desired $\mathrm{N}, \mathrm{N}$-dimethylamines in up to $76 \%$ yield (Fig. 4 ). In all cases, the nitro group is highly selective transformed without affecting the core structure of the CCBs. In addition, dimethylation of nimesulide, a non-steroidal anti-inflammatory drug (NSAID) with analgesic and antipyretic properties ${ }^{48}$, proceeded smoothly in $79 \%$ yield. Furthermore, rhodamine and fluorenone derivatives, which are widely used as fluorescent probes ${ }^{49}$ were successfully transformed (Fig. 4).

from $\mathrm{N}, \mathrm{N}$-dimethylation also selective mono-methylation is possible with paraformaldehyde. Initially, we demonstrated this applying rhodamine derivative 49 (Fig. 5a). Here, the selectivity is easily controlled by the concentration of paraformaldehyde and reaction time. In addition to 51, five selected mono-methylated anilines were synthesized in good yields (Fig. 5b)

Methylation of aliphatic amines and application to pharmaceuticals. Apart from nitroarenes, our protocol allows for the use of a variety of bio-active primary and secondary amines which can be exploited for drug discovery. Hence, this benign and convenient reductive amination process is amenable for late-stage synthetic manipulation of all kinds of $N$-based life science molecules. In this respect, it is important to note that

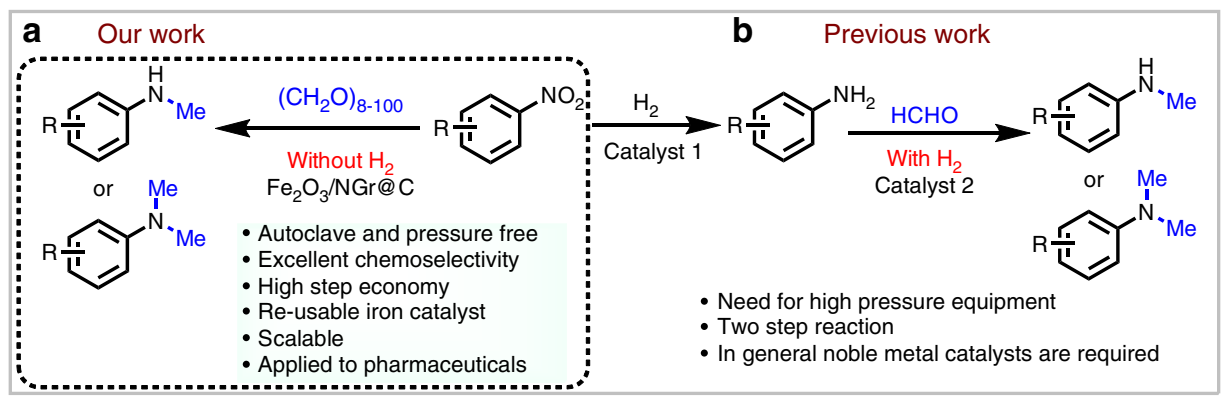

Fig. 2 Reductive methylation of nitroarenes to $\mathrm{N}$-methylamines. a Present work representing the straight forward synthesis of $\mathrm{N}$-methylamines from nitroarenes without external hydrogen. b Previous works showing two-step process for the preparation of $\mathrm{N}$-methylamines in presence of external hydrogen

Table 1 Reductive $\mathrm{N}$-methylation of 4-nitroanisole using Pd/C- and $\mathrm{Fe}_{2} \mathrm{O}_{3} / \mathrm{NGr} @ \mathrm{C}$-catalysts ${ }^{\mathrm{a}}$

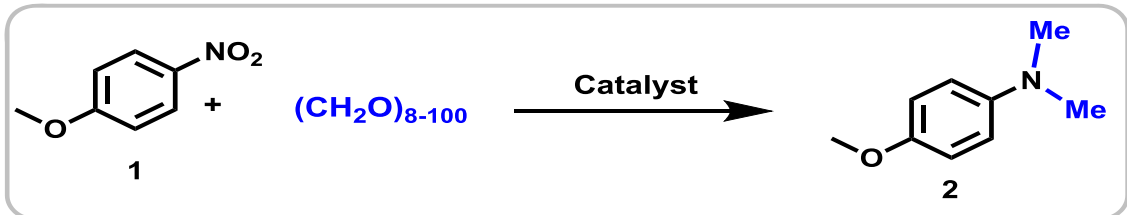

\begin{tabular}{|c|c|c|c|}
\hline Entry & Catalyst & $\mathbf{H}_{2}$ & Yield of $2(\%)$ \\
\hline 1 & $\mathrm{Pd} / \mathrm{C}$ & 50 bar & 77 \\
\hline 2 & $\mathrm{Fe}_{2} \mathrm{O}_{3} / \mathrm{NGr} @ \mathrm{C}$ & 50 bar & 87 \\
\hline 3 & $\mathrm{Pd} / \mathrm{C}$ & 5 bar & 76 \\
\hline 4 & $\mathrm{Fe}_{2} \mathrm{O}_{3} / \mathrm{NGr} @ \mathrm{C}$ & 5 bar & 86 \\
\hline 5 & $\mathrm{Pd} / \mathrm{C}$ & 1 bar & 80 \\
\hline 6 & $\mathrm{Fe}_{2} \mathrm{O}_{3} / \mathrm{NGr} @ \mathrm{C}$ & 1 bar & 85 \\
\hline 7 & $\mathrm{Pd} / \mathrm{C}$ & - & 30 \\
\hline 8 & $\mathrm{Fe}_{2} \mathrm{O}_{3} / \mathrm{NGr} @ \mathrm{C}$ & - & 86 \\
\hline
\end{tabular}




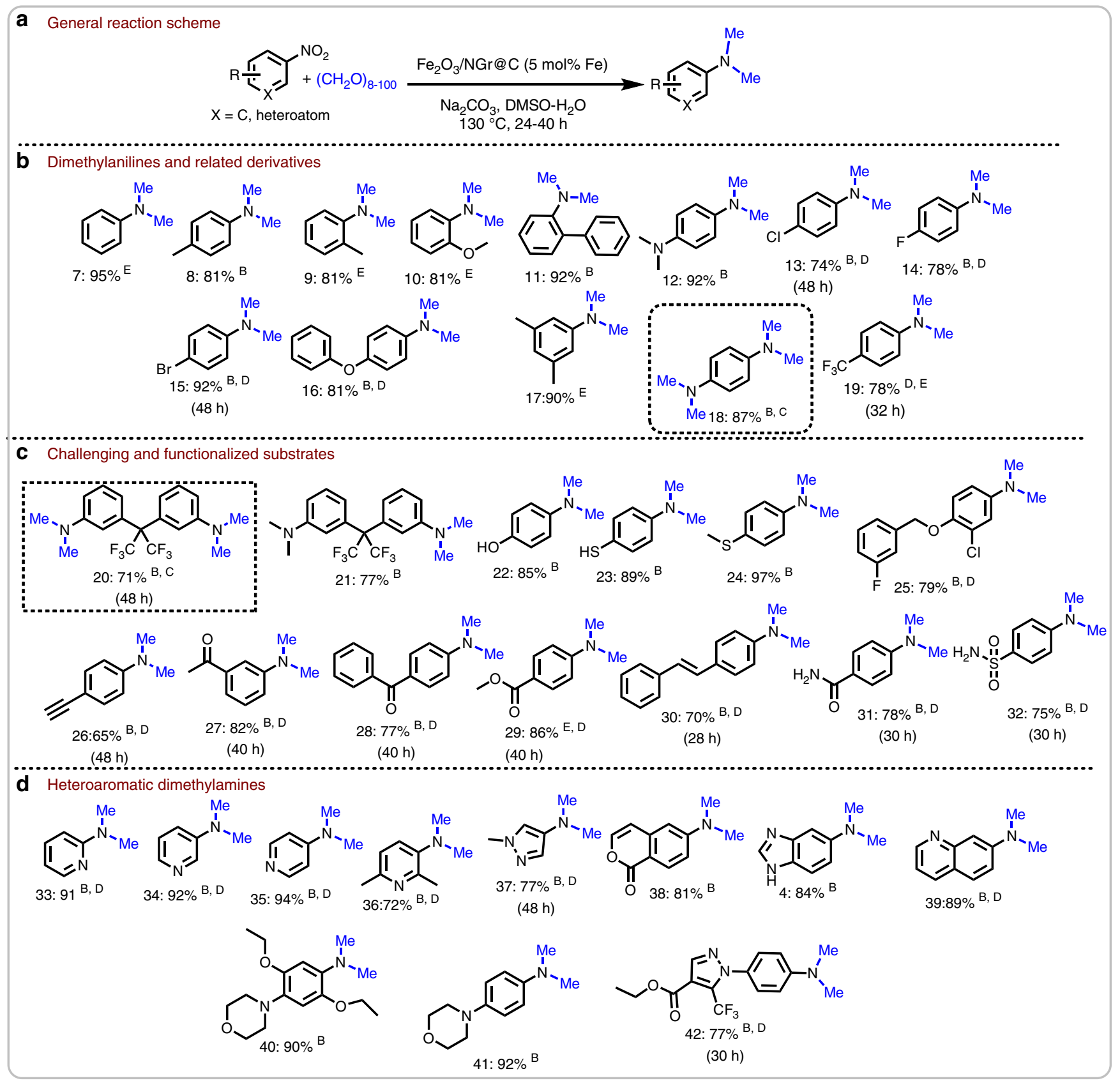

Fig. 3 Synthesis of (hetero)aromatic N,N-dimethylamines ${ }^{A}$. a General scheme representing reductive amino-methylation. $\mathbf{b}$ Synthesis of dimethylanilines and related derivatives. c Synthesis challenging and functionalized dimethylamines. $\mathbf{d}$ Synthesis of heteroaromatic dimethylamines ${ }^{A}$ Reaction conditions: $0.5 \mathrm{mmol}$ nitroarene, $50 \mathrm{mg} \mathrm{Fe} \mathrm{O}_{3} / \mathrm{NGr} @ \mathrm{C}$, ( $5 \mathrm{~mol} \% \mathrm{Fe}$ ), $10 \mathrm{mmol}$ of paraformaldehyde (300 mg), $1 \mathrm{mmol} \mathrm{Na}_{2} \mathrm{CO}_{3}, 2 \mathrm{~mL} \mathrm{DMSO}-\mathrm{mater}(1: 1), 130{ }^{\circ} \mathrm{C}, 24 \mathrm{~h}$. ${ }^{B}$ Isolated yield. ${ }^{C} 100 \mathrm{mg}$ of $\mathrm{Fe}_{2} \mathrm{O}_{3} / \mathrm{NGr} @ \mathrm{C}, 20 \mathrm{mmol}\left(600 \mathrm{mg}\right.$ ) paraformaldehyde, $2 \mathrm{mmol}$ of $\mathrm{Na}_{2} \mathrm{CO}_{3}, 4 \mathrm{~mL} \mathrm{DMSO}-$ water $(1: 1), 130{ }^{\circ} \mathrm{C}, 48 \mathrm{~h} .{ }^{\mathrm{D}} 50 \mathrm{mg}$ $\mathrm{Fe}_{2} \mathrm{O}_{3} / \mathrm{NGr} @ \mathrm{C}, 20 \mathrm{mmol}$ of paraformaldehyde $(600 \mathrm{mg}), 1.5 \mathrm{mmol} \mathrm{Na}{ }_{2} \mathrm{CO}_{3}, 130{ }^{\circ} \mathrm{C}, 24 \mathrm{~h}$. ${ }^{\text {EY }}$ ields were determined by GC

governmental regulations impede the use of toxic metal catalysts at this stage. In this respect, our heterogeneous iron catalyst provides a solution due to its low toxicity and easy removal. Indeed, the methylation of functionalized amines is demonstrated by the synthesis of important existing pharmaceuticals which belong to the 200 top selling drugs (Fig. 6). For example, the naturally occurring alkaloid hordenine ( $N, N$-dimethyltyramine) 50 is prepared in excellent yield from its amine intermediate (Fig. 6). Further, venlafaxine (Effexor), which is used for the treatment of depression and anxiety disorders, is obtained in $89 \%$ yield (Fig. 6) ${ }^{51}$. In addition, reductive methylation of mono- methylated desipramine and nortriptyline gave imipramine and amitriptyline, respectively (Fig. 6) ${ }^{52}$. Moreover, methylation of important active life science molecules such as amlodipine, cinacalcet, duloxetine and sertraline proceeded smoothly (92-95\% yields; Fig. 6) without affecting other functionalities or the core-structure of the molecules.

Gram-scale reactions and recycling of the catalyst. Finally, we wanted to demonstrate the practical utility of our protocol. For this purpose five different $N, N$-dimethylamines were successfully synthesized on $1-10 \mathrm{~g}$ scale (Fig. 7). 


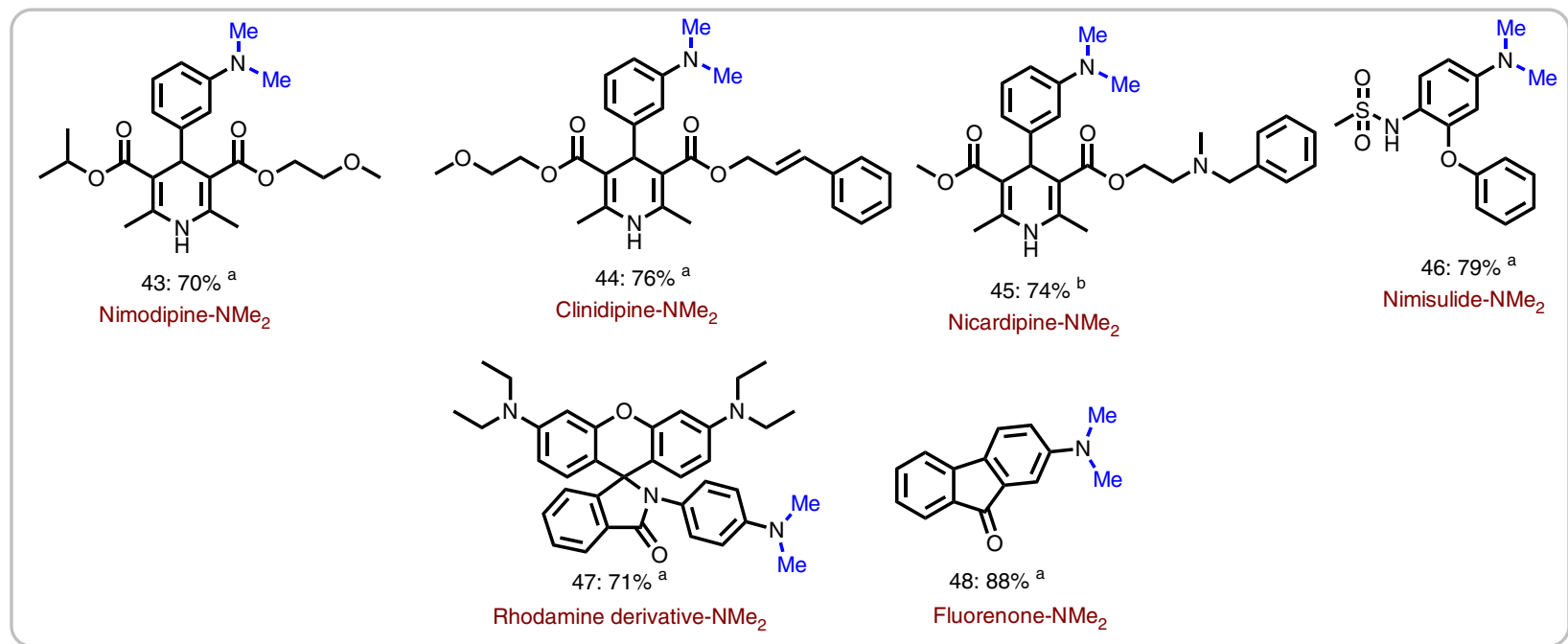

Fig. $4 \mathrm{~N}$-methylation of pharmaceutical and fluorescent molecules ${ }^{\mathrm{a}}$. Selective conversion of nitro groups to $\mathrm{N}$-methyl moiety in selected drug and florescent molecules using iron catalyst. Iron-catalyzed reductive amino-methylation of existing drug molecules a Reaction conditions: $0.5 \mathrm{mmol}$ nitroarene, $50 \mathrm{mg}$ $\mathrm{Fe}_{2} \mathrm{O}_{3} / \mathrm{NGr} @ \mathrm{C}$, (5 mol\% Fe), $10 \mathrm{mmol}$ paraformaldehyde $(300 \mathrm{mg}), 1 \mathrm{mmol} \mathrm{Na}{ }_{2} \mathrm{CO}_{3}, 2 \mathrm{~mL} \mathrm{DMSO}$-water (1:1), $130{ }^{\circ} \mathrm{C}, 30 \mathrm{~h}$, isolated yields. ${ }^{b}$ same as 'a' with $20 \mathrm{mmol}(600 \mathrm{mg}$ ) paraformaldehyde

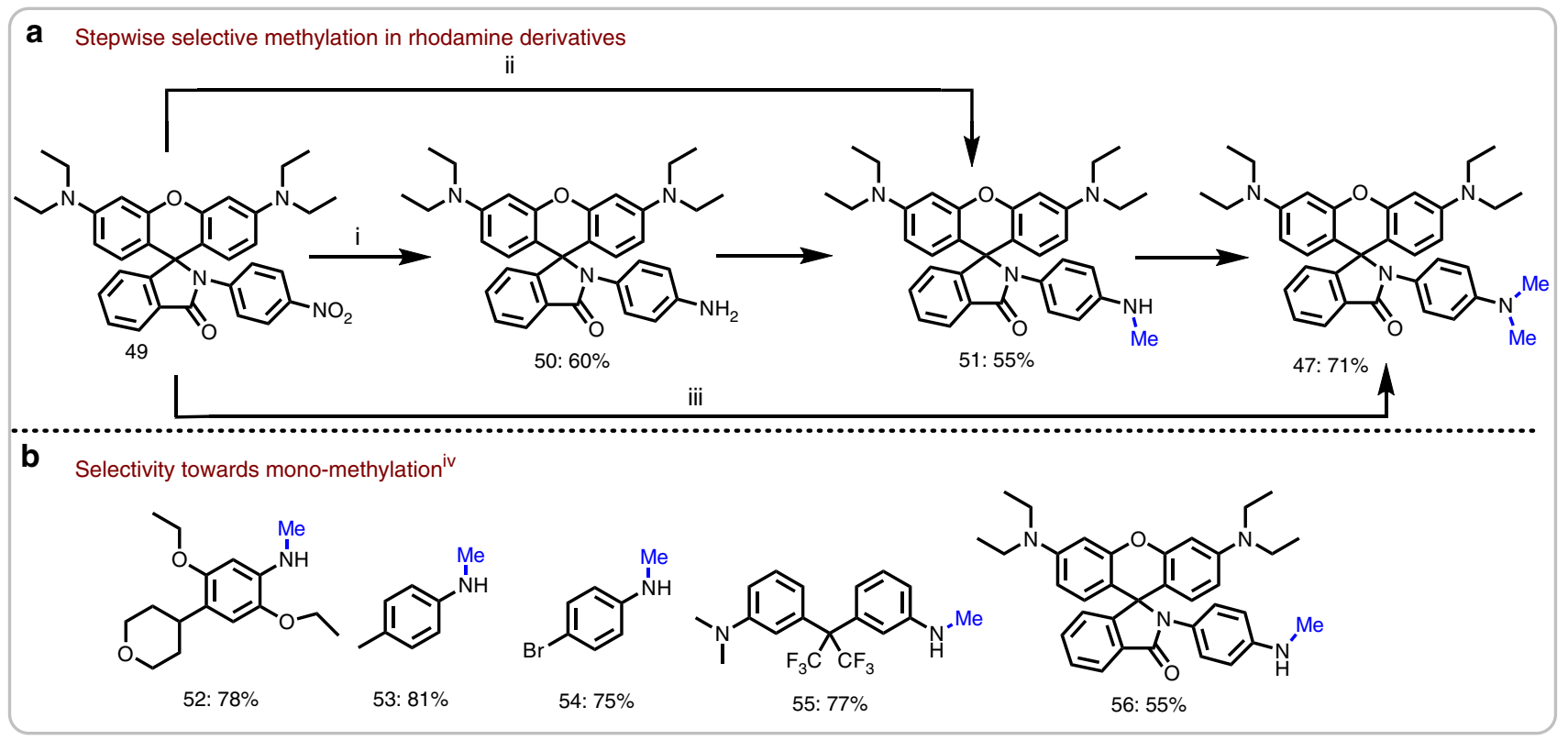

Fig. 5 Controlled stepwise reductive methylation. a Example showing fluorescent compoundi, ii, iii. b Selectivity towards mono-methylation ${ }^{\text {iv }}$. ${ }^{a}$ Reaction conditions a: ${ }^{i} 0.5 \mathrm{mmol}$ of $49,50 \mathrm{mg} \mathrm{Fe} \mathrm{O}_{3} / \mathrm{NGr} @ \mathrm{C}(5 \mathrm{~mol} \% \mathrm{Fe}), 2 \mathrm{mmol}$ paraformaldehyde, $1 \mathrm{mmol} \mathrm{Na}_{2} \mathrm{CO}_{3}, 2 \mathrm{~mL} \mathrm{DMSO}-\mathrm{water}(1: 1), 130{ }^{\circ} \mathrm{C}, 8 \mathrm{~h}$. (b):

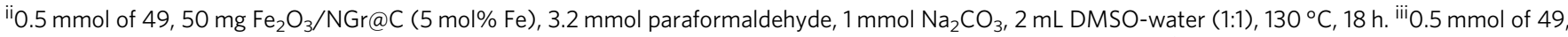
$\mathrm{Fe}_{2} \mathrm{O}_{3} / \mathrm{NGr} @ \mathrm{C}$ ( $5 \mathrm{~mol} \% \mathrm{Fe}$ ), $10 \mathrm{mmol}$ paraformaldehyde, $1 \mathrm{mmol} \mathrm{Na} \mathrm{CO}_{3}, 2 \mathrm{~mL} \mathrm{DMSO}$-water (1:1), $130{ }^{\circ} \mathrm{C}, 30 \mathrm{~h}$. iv Reaction conditions of (B): $0.5 \mathrm{mmol}$ nitroarene, $50 \mathrm{mg} \mathrm{Fe} \mathrm{O}_{3} / \mathrm{NGr@C} \mathrm{(5} \mathrm{mol \%} \mathrm{Fe),} 3.2 \mathrm{mmol}$ paraformaldehyde, $1 \mathrm{mmol} \mathrm{Na} \mathrm{CO}_{3}, 2 \mathrm{~mL}$ DMSO-water $(1: 1), 130^{\circ} \mathrm{C}, 18 \mathrm{~h}$. All are isolated yields

In addition, we demonstrated the stability and re-use of the catalyst. Obviously, such recycling is important for the advancement of cost-effective process development. Notably, our iron catalyst is stable and conveniently recycled up to 5 times without any significant loss of catalytic activity (Fig. 8).

\section{Discussion}

To understand the reasons for this superior activity of the iron catalyst, the mechanism of the underlying reduction process was investigated. Hence, paraformaldehyde was reacted in the presence of $\mathrm{Fe}_{2} \mathrm{O}_{3} / \mathrm{NGr} @ \mathrm{C}$ at $130^{\circ} \mathrm{C}$ for $4 \mathrm{~h}$. Gas analysis (GC) revealed the formation of $\mathrm{H}_{2}, \mathrm{CO}$ and $\mathrm{CO}_{2}$. This result clearly indicates that paraformaldehyde is converted under comparably mild conditions to syngas $\left(\mathrm{CO}+\mathrm{H}_{2}\right)$. Subsequent water-gas shift reaction of $\mathrm{CO}$ in the presence of water produced additional $\mathrm{H}_{2}$ and $\mathrm{CO}_{2}$. Evidently, the small amounts of in situ generated hydrogen allow for selective reduction of nitroarene and the corresponding imine after condensation with formaldehyde to yield the mono- $\mathrm{N}$-methylated product. Following a second condensation with formaldehyde followed by reduction again finally gives the $\mathrm{N}, \mathrm{N}$-dimethylamine (Fig. 9a). Control experiments using ${ }^{13} \mathrm{C}$-labeled paraformaldehyde showed that the methyl 


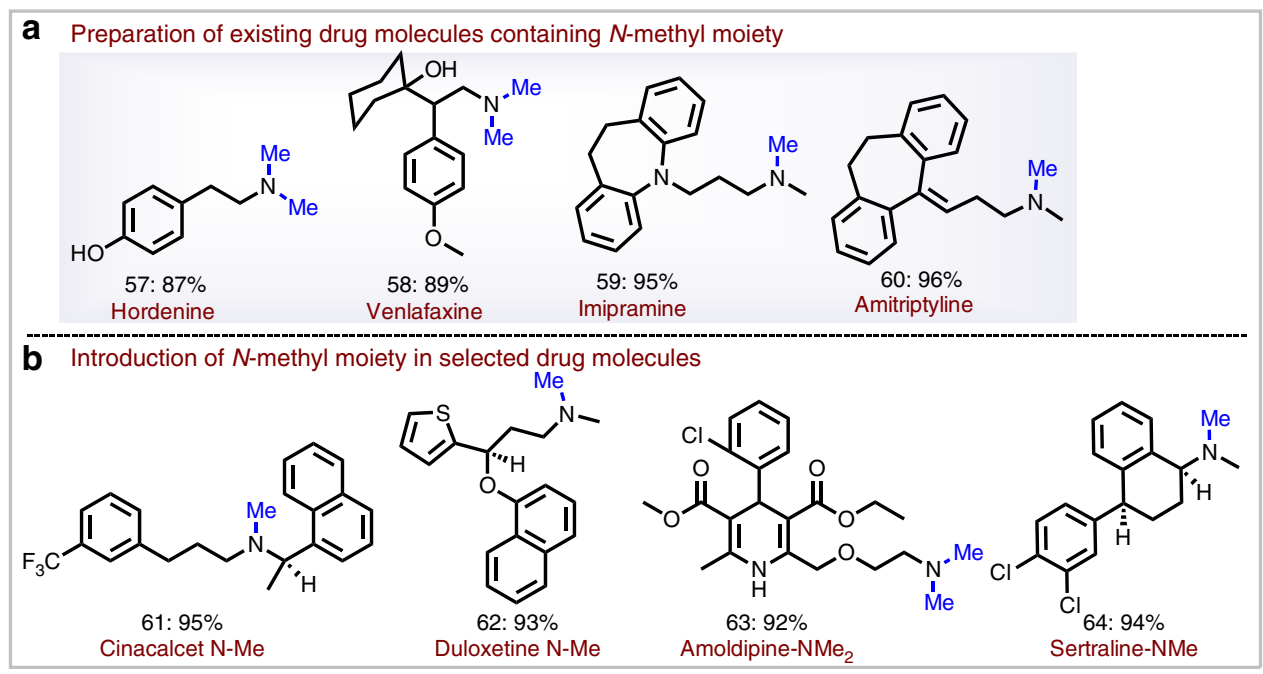

Fig. 6 Synthesis of pharmaceutical $N, N$-(di)methylamines from the corresponding aminesi. a ${ }^{i}$ Reductive amination protocol demonstrating for the

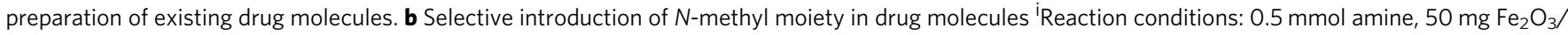
NGr@C (5 mol\% Fe), $5 \mathrm{mmol}$ of paraformaldehyde (150 mg), $0.5 \mathrm{mmol} \mathrm{Na} \mathrm{CO}_{3}, 2 \mathrm{~mL}$ DMSO-water (1:1), $130{ }^{\circ} \mathrm{C}, 24 \mathrm{~h}$, isolated yields

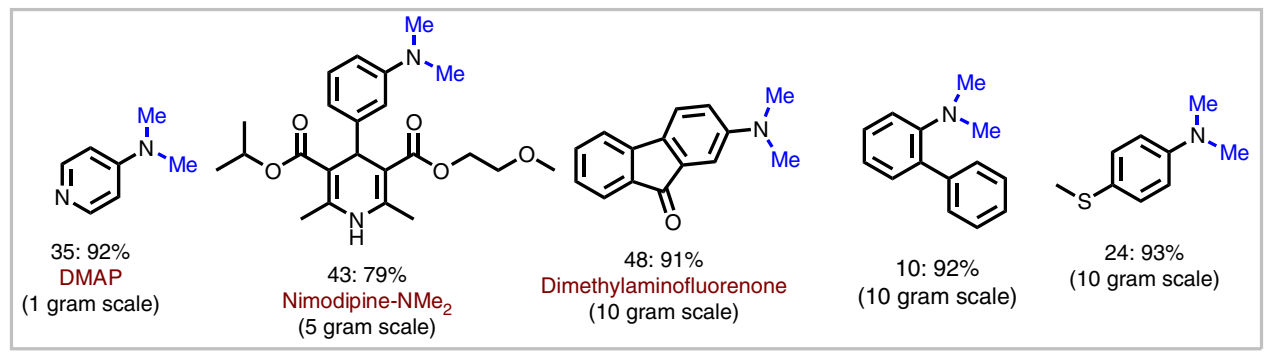

Fig. 7 Gram-scale reactions. Demonstrating the practical utility for the synthesis of selected $\mathrm{N}$-methylamines in up to $10 \mathrm{~g}$. Reaction conditions: $1-10 \mathrm{~g}$ nitroarenes; 5 mol\% $\mathrm{Fe}_{2} \mathrm{O}_{3} / \mathrm{NGr} @ \mathrm{C}, 300 \mathrm{mg}$ paraformaldehyde $\left(10 \mathrm{mmol}\right.$ ) and $1 \mathrm{mmol} \mathrm{Na} \mathrm{CO}_{3}$ for each 0.5 mmol nitroarenes; $40-200$ mL DMSO-water (1:1); $130{ }^{\circ} \mathrm{C} ; 30-40 \mathrm{~h}$; isolated yields
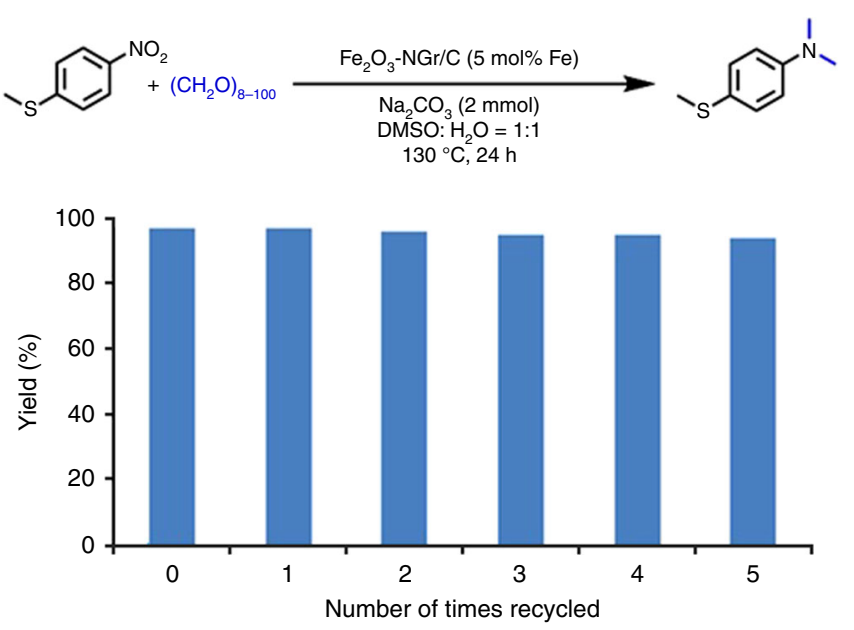

Fig. 8 Catalyst recycling. Recycling and reusability of $\mathrm{Fe}_{2} \mathrm{O}_{3} / \mathrm{NGr} @ \mathrm{C}$ catalyst for the $\mathrm{N}, \mathrm{N}$-dimethylation of 4-nitrothioanisole. ${ }^{\mathrm{a}}$ Reaction conditions: $1 \mathrm{mmol}$ 4-Nitrothioanisole, $100 \mathrm{mg}$ catalyst ( $5 \mathrm{~mol} \%$ ), $600 \mathrm{mg}$ paraformaldehyde, $2 \mathrm{mmol} \mathrm{Na} \mathrm{CO}_{3}, 4 \mathrm{~mL}$ DMSO-water (1:1), $130^{\circ} \mathrm{C}$, 24-30 h, yields were determined by GC groups of the amine result selectively from paraformaldehyde and not from DMSO, which is used as reaction medium (Fig. 9b). Notably, in the overall reaction paraformaldehyde serves both as methylation and reducing agent for the one-pot reductive amination of nitroarenes (Fig. 9b, ii).

In conclusion, we have developed a straightforward, convenient and step economic reductive amino-methylation process starting from easily available nitroarenes using an earth-abundant and reusable iron oxide-based nanocatalyst. In this convenient pressure-free protocol, paraformaldehyde serves as both methylation and in situ generated hydrogen source that avoids the necessity of any specialized equipment and also use of additional reducing agents. Applying this operationally simple methodology, we synthesized a series of functionalized and structurally diverse $\mathrm{N}$-methylamines. The synthetic utility of this reaction is specifically demonstrated using various life science molecules including existing pharmaceuticals.

\section{Methods}

General considerations. Nitro compounds and amines were obtained from various chemical companies. Carbon powder, VULCAN ${ }^{\circledR}$ XC72R with Code XVC72R and CAS No. 1333-86-4 was obtained from Cabot Corporation Prod. $\mathrm{TiO}_{2}$ (P25), $\mathrm{Al}_{2} \mathrm{O}_{3}$ and paraformaldehyde were obtained from Sigma-Aldrich. The pyrolysis experiments were carried out in Nytech-Qex oven. 


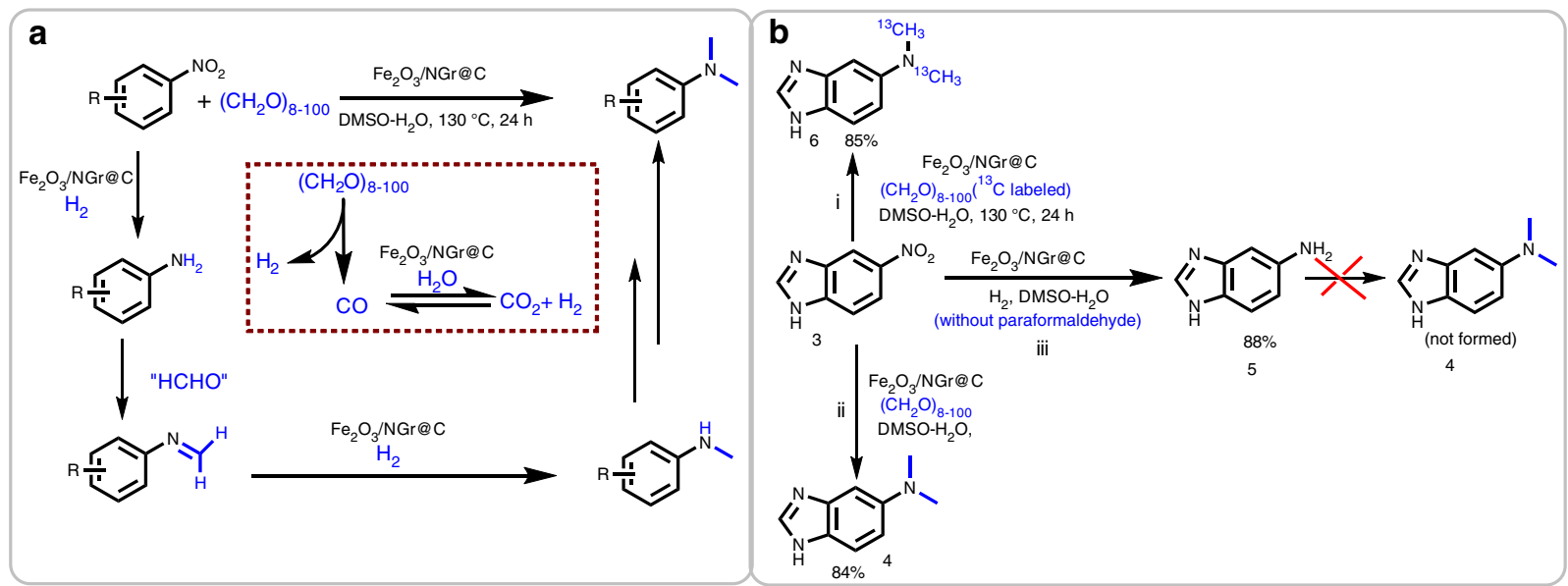

Fig. 9 Iron-catalyzed reductive $\mathrm{N}$-methylation ${ }^{\mathrm{a}}$. a Reaction pathway showing stepwise reductive methylation of nitro compounds. $\mathbf{b}^{13} \mathrm{C}$-Labeled experiment showing paraformaldehyde as $\mathrm{C} 1$ source ${ }^{\mathrm{i}}$, ii, iii. Reaction conditions: ${ }^{\mathrm{i}} 0.5 \mathrm{mmol}$ of 5 -nitrobenzimidazole, $10 \mathrm{mmol}$ of ${ }^{13} \mathrm{C}$-labeled paraformaldehyde (300 mg), $50 \mathrm{mg} \mathrm{Fe} \mathrm{O}_{3} / \mathrm{NGr} @ \mathrm{C}\left(5 \mathrm{~mol} \% \mathrm{Fe}\right.$ ), $1 \mathrm{mmol} \mathrm{Na} \mathrm{CO}_{3}$ (106 mg), $2 \mathrm{~mL}$ DMSO-water (1:1), $130{ }^{\circ} \mathrm{C}, 24 \mathrm{~h}$. ii $0.5 \mathrm{mmol}$ of 1, $10 \mathrm{mmol}$ paraformaldehyde (300 mg), $50 \mathrm{mg} \mathrm{Fe} \mathrm{O}_{3} / \mathrm{NGr} @ \mathrm{C}\left(5 \mathrm{~mol} \% \mathrm{Fe}\right.$ ), 1 mmol Na${ }_{2} \mathrm{CO}_{3}$ (106 mg), $2 \mathrm{~mL}$ DMSO-water (1:1), $130{ }^{\circ} \mathrm{C}, 24 \mathrm{~h}$. iii $0.5 \mathrm{mmol}$ of 1, 50 bar $\mathrm{H}_{2}, 50$ mg Fe $\mathrm{O}_{3} / \mathrm{NGr} @ \mathrm{C}$ ( $5 \mathrm{~mol} \% \mathrm{Fe}$ ), $1 \mathrm{mmol} \mathrm{Na} \mathrm{CO}_{3}(106 \mathrm{mg}), 2 \mathrm{~mL}$ DMSO-water $(1: 1), 130^{\circ} \mathrm{C}, 24 \mathrm{~h}$. All are isolated yields

TEM measurements were performed at $200 \mathrm{kV}$ with an aberration-corrected JEM-ARM200F (JEOL, Corrector: CEOS). The microscope is equipped with a JED2300 (JEOL) energy-dispersive x-ray-spectrometer (EDXS) for chemical analysis. The samples were deposited without any pre-treatment on a holey carbon supported Cu-grid (mesh 300) and transferred to the microscope. The High-Angle Annular Dark Field (HAADF) and Annular Bright Field (ABF) images were recorded with a spot size of approximately $0.1 \mathrm{~nm}$, a probe current of $120 \mathrm{pA}$ and a convergence angle of $30-36^{\circ}$. The collection semi-angles for HAADF and ABF were 70-170 mrad and 11-22 mrad, respectively.

XPS data were obtained with a VG ESCALAB220iXL (ThermoScientific) with monochromatic $\mathrm{Al} \mathrm{K \alpha}(1486.6 \mathrm{eV})$ radiation. The electron binding energies $\mathrm{E}_{\mathrm{B}}$ were obtained without charge compensation. For quantitative analysis the peaks were deconvoluted with Gaussian-Lorentzian curves, the peak areas were divided by a sensitivity factor obtained from the element specific Scofield factor and the transmission function of the spectrometer.

EPR spectra in X-band were recorded on a Bruker EMX CW-micro spectrometer equipped with an ER 4119HS-WI high-sensitivity cavity and a variable temperature control unit using the following parameters: microwave power $=6.64 \mathrm{~mW}$, modulation frequency $=100 \mathrm{kHz}$, modulation amplitude $=1 \mathrm{G}$.

Mössbauer spectra were obtained at $300 \mathrm{~K}$ and $77 \mathrm{~K}$ by a Mössbauer spectrometer from Wissel $\mathrm{GmbH}$ equipped with $\mathrm{a}^{57} \mathrm{Co}$ source. Isomer shifts are given relative to $\alpha$-Fe at room temperature. The spectra were analyzed by leastsquare fits using Lorentzian line shapes.

All catalytic experiments were carried out in ACE pressure $(10 \mathrm{~mL})$ tubes. GC conversions and yields were determined by GC-FID, HP6890 with FID detector, column HP530 $\mathrm{m} \times 250 \mathrm{~mm} \times 0.25 \mu \mathrm{m}$. NMR data were recorded on a Bruker ARX 300 and Bruker ARX 400 spectrometers.

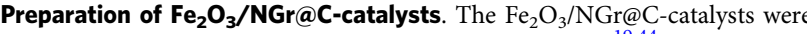
prepared according to our previously reported procedures ${ }^{19,44}$. Appropriate amounts of $\mathrm{Fe}(\mathrm{OAc})_{2}$ and 1,10-phenanthroline (phen; L1) corresponding to $3 \mathrm{wt} \%$ of $\mathrm{Fe}$ (1:3 molar ratio of $\mathrm{Fe}$ to phenanthroline) were stirred in ethanol for $30-40 \mathrm{~min}$ at room temperature. Then, carbon powder (VULCAN ${ }^{\circledR} \mathrm{XC72R}$ ) was added and the reaction mixture was stirred at $60^{\circ} \mathrm{C}$ for $15 \mathrm{~h}$. The reaction mixture was cooled to room temperature and ethanol was slowly removed in vacuo. The solid material obtained was dried at $60^{\circ} \mathrm{C}$ for $12 \mathrm{~h}$, after which was ground to a fine powder. Then, the grinded powder was pyrolyzed at the defined temperature (200, $400,600,800$, or $1000^{\circ} \mathrm{C}$ ) for $2 \mathrm{~h}$ under an argon atmosphere and cooled to room temperature.

Elemental analysis of Fe-phenanthroline/C (Fe-phen/C-800, pyrolyzed at $800^{\circ} \mathrm{C}$ for $2 \mathrm{~h}$ ) (wt $\left.\%\right): \mathrm{C}=91.1, \mathrm{H}=0.19, \mathrm{~N}=2.69, \mathrm{Fe}=2.95$.

The same procedure was applied for the preparation of Fe-with other nitrogen

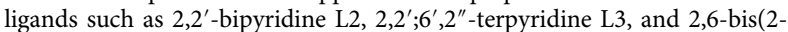
benzimidazolyl)pyridine L4 supported on carbon and also for L1 supported on $\mathrm{TiO}_{2}$ and $\mathrm{Al}_{2} \mathrm{O}_{3}$.

The optimal catalyst used for the model studies and the preparation of the diverse amines has been previously characterized. For details see ref. ${ }^{44}$ of this paper.
Reductive methylation of nitroarenes using $\mathrm{Fe}_{2} \mathrm{O}_{3} / \mathrm{NGr} @ \mathrm{C}$-catalysts. An oven-dried $15 \mathrm{~mL}$ ACE pressure tube with stir bar was charged with $\mathrm{Fe}_{2} \mathrm{O}_{3} / \mathrm{NGr} @ \mathrm{C}$ ( $5 \mathrm{~mol} \% \mathrm{Fe})$, paraformaldehyde $(10-20 \mathrm{mmol}), \mathrm{Na}_{2} \mathrm{CO}_{3}(1 \mathrm{mmol})$, nitroarenes or amine $(0.5 \mathrm{mmol})$, and dimethyl sulfoxide DMSO-water $(1: 1,2 \mathrm{~mL})$. The pressure tube was flushed with argon, closed with screw cap and the reaction was allowed to progress at $130-150^{\circ} \mathrm{C}$ for desired time $(24-40 \mathrm{~h})$. After the completion of the reaction, the pressure tube was cooled down to room temperature and screw cap was opened. The catalyst was separated from the reaction products by filtration through celite. The separated catalyst along with celite was washed first with acetone and then with ethyl acetate. After solvent evaporation, the obtained crude product was purified by column chromatography (heptane: EtOAc) to afford the pure product which was submitted for analysis.

${ }^{13} \mathrm{C}$ - labeled experiment. An oven-dried $10 \mathrm{~mL}$ pressure tube with stir bar was charged with $\mathrm{Fe}_{2} \mathrm{O}_{3} / \mathrm{NGr} @ \mathrm{C}(5 \mathrm{~mol} \% \mathrm{Fe}),{ }^{13} \mathrm{C}$-paraformaldehyde $(10 \mathrm{mmol})$, $\mathrm{Na}_{2} \mathrm{CO}_{3}$ (1 mmol), 5-Nitrobenzimidazole $(0.5 \mathrm{mmol})$, and dimethyl sulfoxide DMSO-water $(1: 1,2 \mathrm{~mL})$. The pressure tube was flushed with argon, closed with screw cap and the reaction was allowed to progress at $130^{\circ} \mathrm{C}$ for $24 \mathrm{~h}$. After the completion of the reaction, the pressure tube was cooled down to room temperature and screw cap was opened. The catalyst was separated from the reaction products by filtration through celite. The separated catalyst along with celite was washed first with acetone and then with ethyl acetate. After solvent evaporation, the obtained crude product was purified by column chromatography (heptane: EtOAc) to afford the pure product which was submitted for analysis

Procedure for the gram scale reactions. An oven-dried 100-1000-ml round bottom flask, equipped with stirring bar was charged with corresponding nitroarene, $\mathrm{Fe}_{2} \mathrm{O}_{3} / \mathrm{NGr} @ \mathrm{C}$, paraformaldehyde, $\mathrm{Na}_{2} \mathrm{CO}_{3}$, DMSO- $\mathrm{H}_{2} \mathrm{O}$ (For reaction conditions see Fig. 8). The round bottom flask was flushed with argon and then fixed with reflux condenser. The reflux condenser was closed, flushed with Argon and the reaction was allowed to progress at $130^{\circ} \mathrm{C}$ for desired time. After the completion of the reaction, the round bottom flask was cooled down to room temperature and reflux condenser was removed. The catalyst was separated from the reaction products by filtration through celite. The separated catalyst along with celite was washed first with acetone and then with ethyl acetate. After solvent evaporation, the obtained crude product was purified by column chromatography (heptane: EtOAc) to afford the pure product which was submitted for analysis.

Procedure for catalyst recycling. After the reaction similar to the procedure given in section S5.1, the catalyst was separated by centrifugation and thoroughly washed with distilled water, acetone and ethyl acetate sequentially in each run. Then the washed catalyst was dried in high vacuum and was used for the next cycle. see Fig. 9 for the reaction conditions.

Procedure for the detection of gases from paraformaldehyde. $\mathrm{Fe}_{2} \mathrm{O}_{3} / \mathrm{NGr} @ \mathrm{C}$ (5 mol\% Fe, $50 \mathrm{mg}$ ), paraformaldehyde $(10 \mathrm{mmol}), \mathrm{Na}_{2} \mathrm{CO}_{3}$ ( $1 \mathrm{mmol}$ ), DMSOwater $(1: 1,2 \mathrm{~mL})$, and a magnetic stir bar were placed in a vial, which was then 
capped with a septum equipped with a needle. The vial was placed in an autoclave, and heated at $130^{\circ} \mathrm{C}$ for $4-5 \mathrm{~h}$. Subsequently it was cooled down to room temperature and the reaction mixture was directly determined by GC gas phase analysis. See Supplementary Fig. 4 for the GC-spectrum for the detected gases:

Data availability. All data are available from the authors upon reasonable request.

Received: 3 January 2017 Accepted: 15 September 2017

Published online: 07 November 2017

\section{References}

1. Chatterjee, J., Rechenmacher, F. \& Kessler, H. N-Methylation of peptides and proteins: an important element for modulating biological functions. Angew. Chem. Int. Ed. 52, 254-269 (2003).

2. Chatterjee, J., Gilon, C., Hoffman, A. \& Kessler, H. N-Methylation of peptides: a new perspective in medicinal chemistry. Acc. Chem. Res. 41, 1331-1342 (2008).

3. Goldberg, A. D., Allis, C. D. \& Bernstein, B. Epigenetics: a landscape takes shape. Cell 128, 635-638 (2007).

4. Egger, G., Liang, G. N., Aparicio, A. \& Jones, P. A. Epigenetics in human disease and prospects for epigenetic therapy. Nature 429, 457-463 (2004).

5. White, T. R. et al. On-resin N-methylation of cyclic peptides for discovery of orally bioavailable scaffolds. Nat. Chem. Biol. 7, 810-817 (2011).

6. Ratel, D., Ravanat, J.-L., Berger, F. \& Wion, D. N6-methyladenine: the other methylated base ofDNA. Bioessay 28, 309-315 (2006).

7. Barreiro, E. J., Kümmerle, A. E. \& Fraga, C. A. M. The methylation effect in medicinal chemistry. Chem. Rev. 111, 5215-5246 (2011).

8. Bartholow, M. http://www.pharmacytimes.com/publications/issue/2013/ july2013/top-200-drugs-of-2012 (2013)

9. Klankermayer, J., Wesselbaum, S., Beydoun, K. \& Leitner, W. Selective catalytic synthesis using the combination of carbon dioxide and hydrogen: catalytic chess at the interface of energy and chemistry. Angew. Chem. Int. Ed. 55, 7296-7343 (2016).

10. Rapport, Z. The Chemistry of Anilines (Wiley Interscience, 2007).

11. Weissermel, K. \& Arpe, H. J. Industrial Organic Chemistry (Wiley-VCH, 2003).

12. CEH marketing research report: Alkylamines (C1-C6). Chemical Economics Handbook (2014; https://www.ihs.com/products/alkylamines-chemicaleconomics-handbook.html).

13. Eschweiler, W. Ersatz von Stickstoff gebundenen Wasserstoffatomen durch die Methylgruppe mit Hülfe von Formaldehyd. Ber. Dtsch. Chem. Ges. 38, 880-882 (1905).

14. Clarke, H. T., Gillespie, H. B. \& Weisshaus, S. Z. The action of formaldehyde on amines and amino acids. J. Am. Chem. Soc. 55, 4571-4687 (1933).

15. Tanis, M., \& Rauniyar, G. Method For The Reductive Methylation Of Primary Amines. US5105013 A (1992).

16. Sorribes, I., Junge, K. \& Beller, M. General catalytic methylation of amines with formic acid under mild reaction conditions. Chem. Eur. J. 20, 7878-7883 (2014).

17. Li, Y., Sorribes, I., Vicent, C., Junge, K. \& Beller, M. Convenient reductive methylation of amines with carbonates at room temperature. Chem. Eur. J. 21, 16759-16763 (2015)

18. Alinezhad, H., Yavari, H. \& Salehian, F. Recent advances in reductive amination catalysis and its applications. Curr. Org. Chem. 19, 1021-1049 (2015).

19. Jagadeesh, R. V. et al. Precious hydrogenation using iron oxide-based nanocatalysts for synthesis of amines. Nat. Prot. 10, 548-557 (2015).

20. Weiwei, Z. \& Morris, R. H. Synthesis and use of an asymmetric transfer hydrogenation catalyst based on iron(II) for the synthesis of enantioenriched alcohols and amines. Nat. Prot. 10, 241-257 (2015).

21. Plietker, B. Iron Catalysis In Organic Chemistry (Wiley-VCH, 2008).

22. Bolm, C., Legros, J., Le Paih, J. \& Zani, L. Iron-catalyzed reactions in organic synthesis. Chem. Rev. 104, 6217-6254 (2004).

23. Enthaler, S., Junge, K. \& Beller, M. Sustainable metal catalysis with iron: From rust to a rising star. Angew. Chem. Int. Ed. 47, 3317-3321 (2008).

24. Sherry, B. D. \& Fürstner, A. The promise and challenge of iron-catalyzed cross coupling. Acc. Chem. Res. 41, 1500-1511 (2008).

25. Hoyt, H. M., Schmidt, V. A., Tondreau, A. M. \& Chirik, P. J. Iron-catalyzed intermolecular $[2+2]$ cycloadditions of unactivated alkenes. Science $\mathbf{3 4 9}$, 960-963 (2015).

26. Ingmar, B. \& Knölker., H.-J. Iron catalysis in organic synthesis. Chem. Rev. 115, 3170-3387 (2015).

27. Bornschein, C. et al. Mild and selective hydrogenation of aromatic and aliphatic (di)nitriles with a well-defined iron pincer complex. Nat. Commun. 5, 4111 (2014).

28. Hoyt, J. M. et al. Synthesis and hydrogenation activity of iron dialkyl complexes with chiral bidentate phosphines. Organometallics 33, 5781-5790 (2014).
29. Sui-Seng, C., Freutel, F., Lough, A. J. \& Morris, R. H. Highly efficient catalyst systems using iron complexes with a tetradentate PNNP ligand for the asymmetric hydrogenation of polar bonds. Angew. Chem. Int. Ed. 47, 940-943 (2008).

30. Bonitatibus, P. J. Jr et al. Reversible catalytic dehydrogenation of alcohols for energy storage. Proc. Natl Acad. Sci. 112, 1687-1692 (2015).

31. Alberico, E. et al. Selective hydrogen production from methanol with a defined iron pincer catalyst under mild conditions. Angew. Chem. Int. Ed. 52, 14162-14166 (2013).

32. Yan, T., Feringa, B. L. \& Barta, K. Iron catalyzed direct alkylation of amines with alcohols. Nat. Commun. 5, 5602-52068 (2014).

33. Smith, M. B. \& March, J. March's Advanced Organic Chemistry: Reactions, Mechanisms, and Structure 6th edn. (Wiley, 2007).

34. Santhapuram, H. K. R., Dutta, A., Hutt, O. E. \& Georg, G. I. N-Methylation of the $\mathrm{C}^{\prime}$ amide of taxanes: synthesis of $\mathrm{N}$-methyltaxol C \& N-methylpaclitaxel. $J$. Org. Chem. 73, 4705-4708 (2008).

35. Dang, T. T., Ramalingam, B. \& Seayad, A. M. Efficient ruthenium-catalyzed Nmethylation of amines using methanol. ACS Catal. 5, 4082-4088 (2015).

36. Tsarev, V. N. et al. N-methylation of amines with methanol at room temperature. Org. Lett. 17, 2530-2533 (2015).

37. Li, Y., Sorribes, I., Yan, T., Junge, K. \& Beller, M. Selective methylation of amines with carbon dioxide and H2. Angew. Chem. Int. Ed. 52, 12156-12160 (2013).

38. Li, Y., Fang, X., Junge, K. \& Beller, M. A general catalytic methylation of amines using carbon dioxide. Angew. Chem. Int. Ed. 52, 9568-9571 (2013).

39. Das, S., Bobbink, F. D., Laurenczy, G. \& Dyson, P. J. Metal-free catalyst for the chemoselective methylation of amines using carbon dioxide as a carbon source. Angew. Chem. Int. Ed. 53, 12876-12879 (2014).

40. Natte, K., Dumrath, A., Neumann, H. \& Beller, M. Palladium-catalyzed carbonylations of aryl bromides using paraformaldehyde: synthesis of aldehydes and esters. Angew. Chem. Int. Ed. 53, 10090-10094 (2014).

41. Liu, Q., Wu, L., Jackstell, R. \& Beller, M. Ruthenium-catalyzed alkoxycarbonylation of alkenes with paraformaldehyde as a carbon monoxide substitute. ChemCatChem 6, 2805-2809 (2014).

42. van der Waals, D. et al. Ruthenium-catalyzed methylation of amines with paraformaldehyde in water under mild conditions. ChemSusChem 9, 1-6 (2016).

43. Corma, A. \& Serna, P. Chemoselective hydrogenation of nitro compounds with supported gold catalysts. Science 313, 332-334 (2006).

44. Jagadeesh, R. V. et al. Nanoscale $\mathrm{Fe}_{2} \mathrm{O}_{3}$-based catalysts for selective hydrogenation of nitroarenes to anilines. Science 342, 1073-1076 (2013).

45. Cui, X., Zhang, Y., Deng, Y. \& Shi, F. N-methylation of amine and nitro compounds with $\mathrm{CO}_{2} / \mathrm{H}_{2}$ catalyzed by $\mathrm{Pd} / \mathrm{CuZrOx}$ under mild reaction conditions. Chem. Commun. 50, 13521-13524 (2014).

46. $\mathrm{Yu}$, L. et al. Gold-catalyzed reductive transformation of nitro compounds using formic acid: Mild, efficient, and versatile. ChemSusChem 8, 3029-3035 (2015).

47. Elliot, W. J. \& Ram, C. V. S. Calcium channel blockers. J. Clin. Hypertens. 13 687-689 (2011).

48. Traversa, G. et al. Cohort study of hepatotoxicity associated with nimesulide and other non-steroidal anti-inflammatory drugs. BMJ 327, 18-22 (2003).

49. Beija, M., Afonso, C. A. M. \& Martinho, J. M. G. Synthesis and applications of Rhodamine derivatives as fluorescent probes. Chem. Soc. Rev. 38, 2410-2433 (2009).

50. Cheng, C.-S., Ferber, C., Bashford, R. I. Jr \& Grillot, G. F. A new synthesis of hordenine and other p-dialkylaminoethylphenols and some of their derivatives. J. Am. Chem. Soc. 73, 4081-4084 (1951).

51. Showell, G. A. et al. (R)-Sila-venlafaxine: a selective noradrenaline reuptake inhibitor for the treatment of emesis. Bioorg. Med. Chem. Lett. 16, 2555-2558 (2006).

52. Tatsumi, M., Groshan, K., Blakely, R. D. \& Richelson, E. Pharmacological profile of antidepressants and related compounds at human monoamine transporters. Eur. J. Pharmacol. 340, 249-258 (1997).

\section{Acknowledgements}

The Federal Ministry of Education and Research (BMBF) and the State of MecklenburgVorpommern are gratefully acknowledged for their general support. We are grateful to Prof. A. Brückner, Drs. J. Radnik and M.-M. Pohl for catalyst characterization and thankful to the analytical staff of the Leibniz-Institute for Catalysis, Rostock for their excellent service.

\section{Author contributions}

K.N., R.V.J., and M.B. planned and developed the project. K.N., R.V.J., and H.N. designed the experiments. K.N. performed all experiments, isolated and characterized the 
products. R.V.J. and M.B. developed the catalysts. R.V.J., K.N., and M.B. wrote the paper. R.V.J. and M.B. supervised the project.

\section{Additional information}

Supplementary Information accompanies this paper at doi:10.1038/s41467-017-01428-0.

Competing interests: The authors declare no competing financial interests.

Reprints and permission information is available online at http://npg.nature.com/ reprintsandpermissions/

Publisher's note: Springer Nature remains neutral with regard to jurisdictional claims in published maps and institutional affiliations. (c) (i) Open Access This article is licensed under a Creative Commons Attribution 4.0 International License, which permits use, sharing, adaptation, distribution and reproduction in any medium or format, as long as you give appropriate credit to the original author(s) and the source, provide a link to the Creative Commons license, and indicate if changes were made. The images or other third party material in this article are included in the article's Creative Commons license, unless indicated otherwise in a credit line to the material. If material is not included in the article's Creative Commons license and your intended use is not permitted by statutory regulation or exceeds the permitted use, you will need to obtain permission directly from the copyright holder. To view a copy of this license, visit http://creativecommons.org/ licenses/by/4.0/.

(C) The Author(s) 2017 